\title{
PENENTUAN LINGKUNGAN PENGENDAPAN LAPISAN BATUBARA D, FORMASI MUARA ENIM, BLOK SUBAN BURUNG, CEKUNGAN SUMATERA SELATAN
}

\author{
Interpretation of Depositional Environment of Coal Seam D, Muara \\ Enim Formation, Suban Burung Block, South Sumatera Basin
}

\author{
ASEP B. PURNAMA ${ }^{1,2}$, SILTI SALINITA ${ }^{1}$, SUDIRMAN ${ }^{1}$, YOGA A. SENDJAJA ${ }^{3}$ dan BUDI \\ MULJANA ${ }^{3}$ \\ ${ }^{1}$ Pusat Penelitian dan Pengembangan Teknologi Mineral dan Batubara \\ J. Jend. Sudirman 623 Bandung 40211 \\ Telp. (022) 6030483, Fax. (022) 6003373 \\ e-mail : asepb@tekmira.esdm.go.id \\ ${ }^{2}$ Mahasiswa Program Doktor Fakultas Teknik Geologi Universitas Padjajaran \\ JI. Raya Bandung Sumedang KM 21, Jatinangor 45363 \\ Telp. (022) 7796545, Fax. (022) 7796545 \\ 3 Teknik Geologi Universitas Padjajaran \\ Jl. Raya Bandung Sumedang KM 21, Jatinangor 45363 \\ Telp. (022) 7796545, Fax. (022) 7796545
}

\begin{abstract}
ABSTRAK
Lapisan batubara D termasuk ke dalam Blok Suban Burung, Formasi Muara Enim, Subcekungan Palembang Tengah, Cekungan Sumatera Selatan, berumur Miosen Tengah sampai Miosen Akhir. Penelitian ini bertujuan untuk mengetahui karakteristik batubara dan lingkungan terhadap percontoh Lapisan Batubara D dari kegiatan pengeboran penelitian gasifikasi bawah permukaan. Metode yang digunakan adalah analisis petrografi batubara, nilai reflektansi vitrinit, dan interpretasi lingkungan pengendapan berdasarkan diagram Diessel dan diagram Calder. Lapisan batubara ini didominasi oleh vitrinit, rata-rata sekitar $71,1 \%$, diikuti inertinit $17,6 \%$, liptinit 5,9\%, dan mineral 6,4\%. Nilai reflektansi vitrinit berkisar antara 0,25-38\%, termasuk ke dalam peringkat lignit-subbituminus. Berdasarkan hasil rekonstruksi lingkungan pengendapan menggunakan empat parameter TPI (Tissue Preservation Index), GI (Gelification Index), GWI (Ground Water Index) dan VI (Vegetation Index) dan diplot dalam diagram Diessel dan diagram Calder diketahui bahwa Lapisan Batubara D diendapkan dalam lingkungan pengendapan limnik.
\end{abstract}

Kata kunci: lapisan batubara D, lingkungan pengendapan, blok Suban Burung, cekungan Sumatera Selatan.

\begin{abstract}
Coal seam D of the Suban Burung Block, Muara Enim Formation, Central Palembang Sub-Basin, South Sumatera Basin has ages of Middle Miocene to Late Miocene. The purpose of this study is to investigate the characteristics of the coal and its depositional environment. Observations were carried out on coal samples from an exploration drilling for underground coal gasification project. The research method used was petrographic analysis, which was supported by the results of coal vitrinite reflectance. The interpretation of depositional environment uses Diessel and Calder diagrams. Petrographic characteristics indicate that the coal is dominated by vitrinite about $71.1 \%$, inertinite $17.6 \%$, liptinite $5.9 \%$, and $6.4 \%$ mineral matter. Vitrinite reflectance (Rvmax \%) values show
\end{abstract}


0.25 to $0.38 \%$, which correspond to the rank of lignite-subbituminous. Based on the results of coal depositional environment reconstruction using four parameters, namely TPI (Tissue Preservation Index), Gl (Gelification Index), GWI (Ground Water Index) and VI (Vegetation Index), it is interpreted that the coal was deposited in a limnic depositional environment.

Keywords: coal seam D, depositional environment, Suban Burung block, South Sumatera basin.

\section{PENDAHULUAN}

Batubara adalah batuan yang mudah terbakar, terbentuk dari sisa tumbuhan purba, berwarna coklat sampai hitam, yang sejak pengendapannya mengalami proses fisika dan kimia, sehingga terjadi pengayaan pada komposisi karbonnya. Potensi batubara Indonesia cukup banyak, dengan sumber daya sekitar 128 miliar ton dan cadangannya sekitar 40 miliar ton (Badan Geologi, 2016). Batubara di Indonesia pada umumnya berperingkat rendah, yakni antara lignit sampai subbituminus. Namun, ada di beberapa lokasi yang mempunyai peringkat tinggi (antrasit) yang diakibatkan oleh adanya pengaruh intrusi batuan beku, seperti batubara di Air Laya, Sumatera Selatan. Santoso (2015) dan Daulay, Ningrum dan Cook (2000) membagi peringkat batubara di Cekungan Sumatera Selatan berkisar antara subbituminus dengan nilai reflektansi vitrinit (Rvmax\%) 0,40-0,50\% dan antrasit 0,60 $2,60 \%$. Hal tersebut serupa dengan hasil penelitian Amijaya dan Littke (2006), Susilawati dan Ward (2006), Purnama dan Ningrum (2012), Salinita dan Purnama (2014) yang dilakukan pada batubara di daerah Tanjung Enim. Hasil penelitian di daerah Subcekungan Jambi mendapatkan batubara dengan nilai reflektansi vitrinit (Rvmax\%) 0,19-0,25\%, termasuk dalam peringkat lignit (Sumaatmadja dan Iskandar, 2001). Subcekungan Palembang Tengah berisi batubara dengan nilai reflektansi vitrinit Rvmax $\%=0,23-0,3 \%$, termasuk dalam peringkat batubara lignit.

Untuk mengetahui karakteristik batubara, biasanya dilakukan dengan studi petrografi batubara, yaitu pendekatan melihat komponen organik dan anorganik secara mikroskopis, yang menekankan pada cara pemerian dan klasifikasi batubara secara sistematis (Stach dkk., 1982; Suárez-Ruiz dan Crelling, 2008). Hasil studi ini dapat dipakai untuk menafsirkan lingkungan pengendapan batubara, sejarah geotermal, prediksi potensi pemanfaatan batubara, serta eksplorasi minyak dan gas bumi (Santoso, 2015). Studi ini bertujuan untuk mengetahui lingkungan pengendapan batubara dan peringkat batubara untuk pengembangan underground coal gasification (UCG) pada Formasi Muara Enim, di daerah Blok Suban Burung, Subcekungan Palembang Tengah, Cekungan Sumatera Selatan.

Batubara yang cocok untuk pengembangan underground coal gasification (UCG) adalah lignit sampai bituminus (Khadse dkk., 2007; Friedmann, Upadhye dan Kong, 2009; Kreynin, 2012; Bhutto, Bazmi dan Zahedi, 2013; Imran dkk., 2014). Selain karakteristik batubara, perlu juga dikaji karakteristik kedalaman, ketebalan, kualitas, kondisi struktur dan lapisan penutup batubara (Santoso, 2015).

Daerah penelitian berada di Desa Macang Sakti, Kecamatan Sanga Desa, Kabupaten Musi Banyuasin. Lokasi ini dapat dicapai dengan menempuh perjalanan 5 jam dari Palembang dengan menggunakan roda empat ke arah Musi Banyuasin (Gambar 1).

\section{GEOLOGI REGIONAL}

Secara regional, daerah penelitian terletak dalam Blok Suban Burung di peta geologi lembar Sarolangun (Suwarna dkk., 1992). Daerah ini mempunyai morfologi yang cukup bergelombang dengan elevasi sekitar $74-81 \mathrm{~m}$ di atas permukaan laut. Berdasarkan peta geologi regional, daerah penelitian berada pada Cekungan Sumatera Selatan yang dipengaruhi oleh aktivitas tektonik pergerakan lempeng kerak bumi, yakni Lempeng Eurasia dan Lempeng Samudra Hindia (Darman, 2000). Interaksi kedua lempeng ini mengakibatkan deformasi yang sangat kuat pada kompleks batuan berumur Mesozoikum dan Paleozoikum sepanjang Pegunungan Barisan yang terletak agak sisi barat Sumatera. Di sebelah timur pegunungan tersebut, pada sisi barat Paparan Sunda, berderet cekungan Tersier yang berkembang, dan salah satunya adalah Cekungan Sumatera Selatan. 


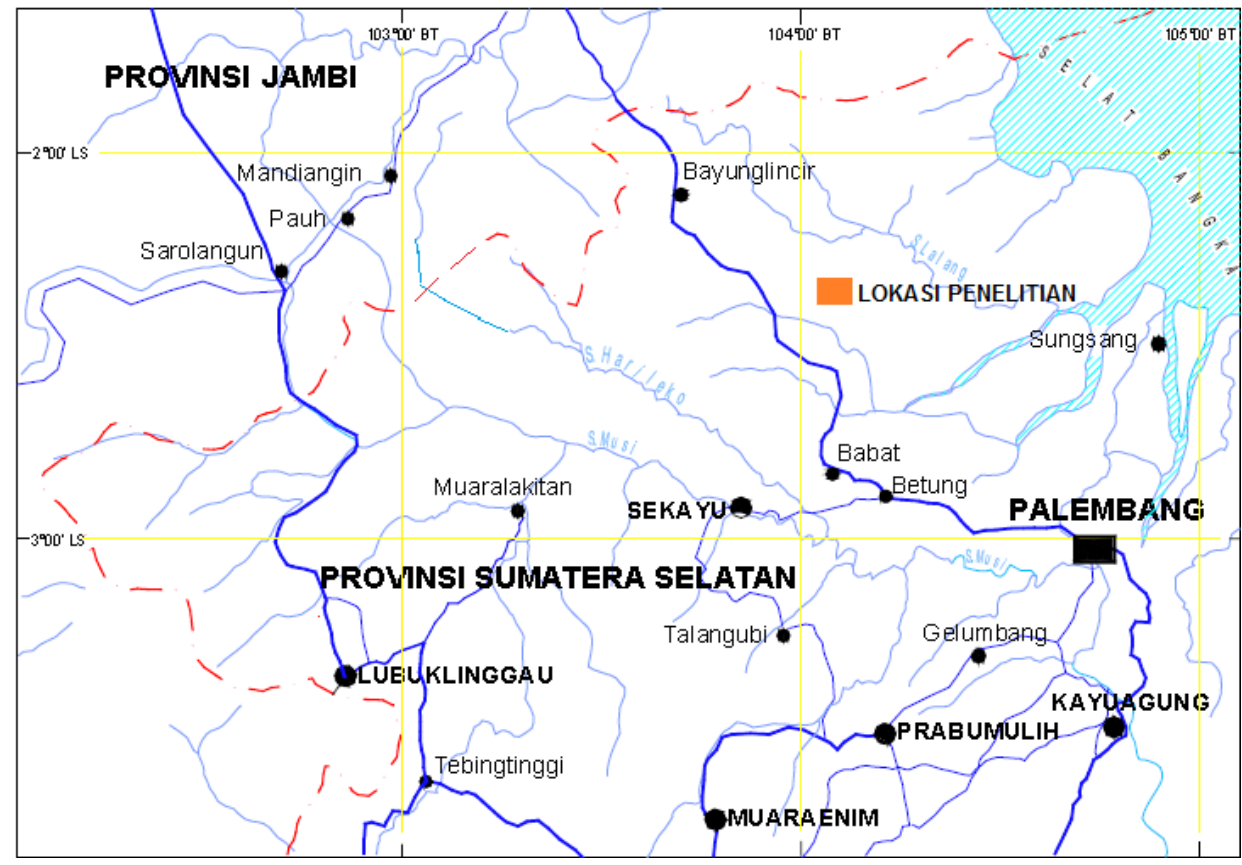

Gambar 1. Lokasi penelitian (modifikasi dari Sumaatmadja dan Iskandar, 2001)

Siklus sedimentasi berkembang pada Cekungan Sumatera Selatan pada daerah rawa yang sangat luas dan batubara terbentuk pada lingkungan paralik-limnik dan air payau (Koesoemadinata, 2000).

Kerangka tektonik Cekungan Sumatera Selatan terdiri atas Paparan Sunda di sebelah timur dan jalur tektonik Bukit Barisan di sebelah barat. Daerah cekungan ini dibatasi oleh Cekungan Jawa Barat dan Tinggian Lampung.

Cekungan Sumatera Selatan dan Cekungan Sumatera Tengah merupakan satu cekungan besar yang dipisahkan oleh Pegunungan Tigapuluh. Cekungan-cekungan ini terbentuk akibat adanya pergerakan ulang sesar bongkah pada batuan Pra-Tersier serta diikuti oleh kegiatan vulkanik. Daerah Cekungan Sumatera Selatan dibagi menjadi depresi Jambi di utara, Subcekungan Palembang Utara, Subcekungan Palembang Tengah dan Subcekungan Palembang Selatan atau Depresi Lematang (van Gorsel, 1988; Bishop, 2001), masingmasing dipisahkan oleh tinggian batuan dasar.

Di daerah Sumatera Selatan terdapat 3 antiklinorium utama, dari selatan ke utara: Antiklinorium Muara Enim, Antiklinorium Pendopo Benakat dan Antiklinorium Palembang. Struktur geologi yang berkembang akibat gaya tegasan yang bekerja dengan arah barat daya-timur laut membentuk lipatan dan sesar. Struktur lipatan membentuk Antiklinorium Pendopo-Benakat. Jurus perlapisan umum masing-masing antiklin dan sinklin berarah barat laut-tenggara yang sesuai dengan arah memanjang Sumatera (Gambar 2).

\section{Stratigrafi Regional}

Sedimentasi di Cekungan Sumatera Selatan berlangsung menerus selama Zaman Tersier disertai dengan penurunan dasar cekungan hingga ketebalan sedimen mencapai 600 meter (van Bemmelen, 1949). Siklus pengendapan di cekungan ini terbagi dalam 2 fase (Jackson, 1961), yaitu:

1. Fase Transgresif, menghasilkan endapan Kelompok Telisa yang terdiri atas Formasiformasi: Lahat, Talang Akar, Baturaja dan Gumai. Kelompok Telisa ini diendapkan tidak selaras di atas batuan dasar berumur Pra-Tersier.

2. Fase Regresif, menghasilkan endapan Kelompok Palembang yang terdiri atas Formasi-formasi: Air Benakat, Muara Enim dan Kasai. Koesoemadinata (2000) mengemukakan bahwa sedimentasi yang terjadi selama Tersier berlangsung pada lingkungan laut setengah tertutup. 


\section{GEOLOGI REGIONAL}
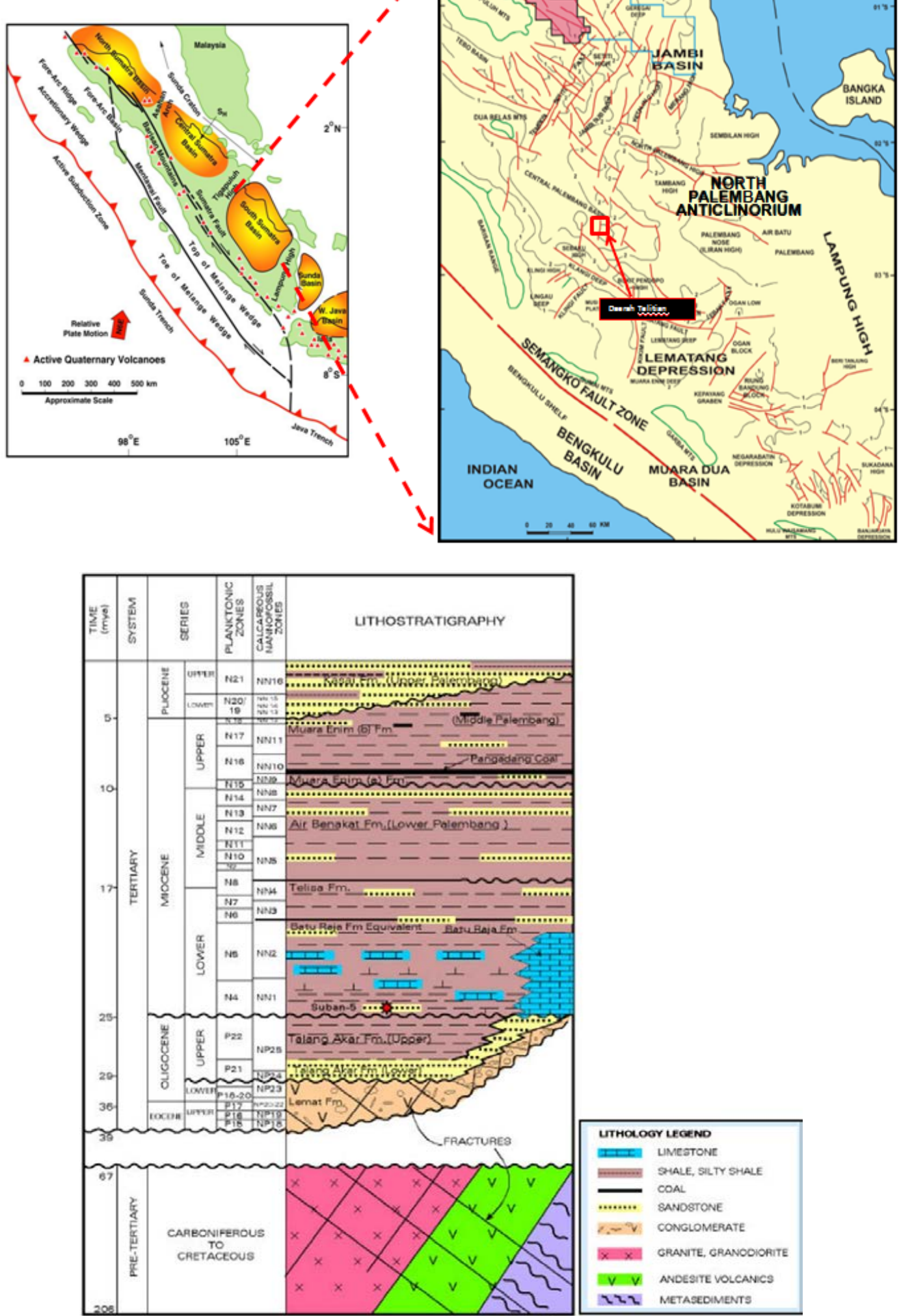

Gambar 2. Peta geologi regional (Gafoer, Amin dan Purnomo, 2007) 
Pada fase transgresif terbentuk urutan fasies darat-transisi-laut dangkal, sedangkan pada fase regresif terbentuk urutan sebaliknya, yaitu laut dangkal-transisi-darat. Stratigrafi cekungan ini dapat dikenal satu daur besar yang terdiri atas suatu transgresi yang diikuti regresi. Endapan Tersier pada cekungan ini, dari tua ke muda, terdiri atas Formasi-formasi: Lahat, Talang Akar, Baturaja, Gumai, Air Benakat.

De Coster (1974) menyimpulkan bahwa batuan dan endapan batubara yang termasuk ke dalam Formasi Muara Enim memiliki siklus pengendapan regresif.

\section{Geologi Lokal}

Lokasi penelitian termasuk ke dalam Subcekungan Palembang Tengah, berada pada daerah perbukitan bergelombang berkemiringan 3-15\%, dengan batuan penyusun terdiri atas sedimen klastik yang terbagi ke dalam dua satuan batuan, yaitu Satuan Batupasir dan Satuan Batupasir Perselingan Batulempung (Gambar 3). Kondisi penyebaran lapisan batubara relatif menerus, terjadi penebalan dan penipisan batubara. Arah penyebarannya relatif barat laut-tenggara dengan kemiringan lapisan ke arah barat daya $\left(\mathrm{N} 120^{\circ} \mathrm{E} / 20^{\circ}\right)$. Di lokasi penelitian didapatkan singkapan Lapisan Batubara L dan Lapisan Batubara $\mathrm{K}$ dengan lebar singkapan $1 \mathrm{~m}$, sedangkan Lapisan Batubara D ditemukan di sebelah utara lokasi penelitian dengan lebar singkapan $34 \mathrm{~m}$. Dari hasil pengeboran, sedikitnya didapatkan 5 lapisan batubara utama, yaitu L, K, J, F dan D. Lapisan yang diteliti adalah Lapisan Batubara D dengan kondisi batubara berwarna hitam kekusaman, terdapat cleat batubara, belah sampai belah konkoidal, dan terdapat damar.

\section{METODE}

Metode yang digunakan dalam penelitian ini berupa analisis petrografi batubara dengan mengamati percontoh batubara berbentuk sayatan poles di bawah mikroskop sinar pantul yang dilengkapi dengan sinar fluoresen dan mesin penghitung untuk perhitungan kuantitatif pengamatan.

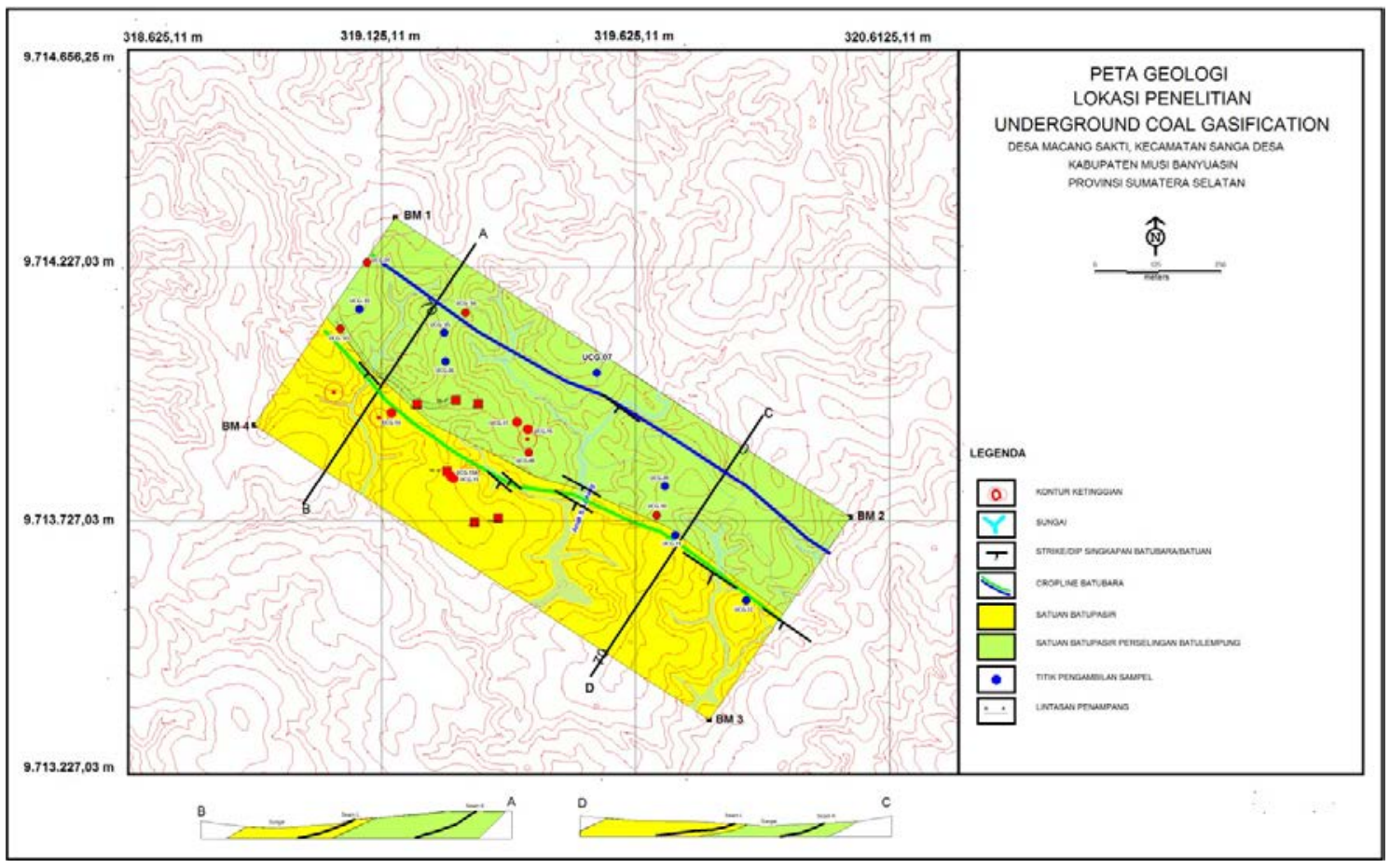

Gambar 3. Peta geologi daerah penelitian 
Analisis maseral dilakukan berdasarkan perhitungan lintasan 500 pengamatan dengan menggunakan mesin penghitung yang dihubungkan dengan mikroskop. Lintasan pengamatan dilakukan dari atas ke bawah pada sayatan poles dengan panjang langkah pengamatan 0,5 $\mathrm{mm}$. Berdasarkan pengamatan tersebut, persentase volume setiap maseral dan mineral dapat dihitung, hingga mendapatkan persentase komposisi maseral untuk penentuan lingkungan pengendapan berdasarkan parameter TPI (Tissue Preservation Index), GI (Gelification Index), GWI (Ground Water Index) dan VI (Vegetation Index).

Selain itu juga dilakukan analisis reflektansi vitrinit pada masing-masing percontoh sebanyak 30x untuk mengetahui nilai reflektansi maksimum rata-rata, sehingga dapat diketahui tingkat kematangan batubara tersebut. Analisis reflektansi vitrinit adalah analisis untuk menentukan besarnya intensitas sinar yang dipantulkan kembali oleh maseral vitrinit. Peningkatan besaran intensitas ini bersifat progresif dengan meningkatnya pembatubaraan, sehingga dapat digunakan sebagai parameter tingkat kematangan (peringkat) suatu lapisan batubara.

Pengukuran reflektansi vitrinit dilakukan di bawah minyak imersi (immersion oil) yang memiliki indeks refraksi 1,52 pada panjang gelombang $546 \mathrm{~nm}$ dan temperatur $23^{\circ} \mathrm{C}$. Untuk mendapatkan hasil pengukuran yang akurat, digunakan standar reflektansi yang diketahui. Dalam penelitian ini standar reflektansi yang digunakan adalah spinel sintetik dengan besaran reflektansi 0,586\%. Pengukuran standar reflektansi dilakukan sebelum pengukuran reflektansi vitrinit. (Tabel 1; ASTM D2798-06, 2006).

Tabel 1. Hubungan reflektansi vitrinit dan peringkat batubara (ASTM D2798-06, 2006)

\begin{tabular}{cc}
\hline Rv max $(\%)$ & Peringkat Batubara \\
\hline$<0,2$ & gambut \\
$0,2-0,35$ & brown coal/lignit \\
$0,35-0,70$ & subbituminus \\
$0,70-1,10$ & bituminus zat terbang tinggi \\
$1,10-1,50$ & bituminus zat terbang menengah \\
$1,50-1,90$ & bituminus zat terbang rendah \\
$1,90-2,20$ & semi-antrasit \\
$>2,20$ & antrasit \\
\hline
\end{tabular}

Percontoh sayatan poles yang diamati diambil dari inti bor Lapisan Batubara D dari kegiatan pengeboran di 7 titik pengeboran, yaitu UCG 2, UCG 5, UCG 6, UCG 7, UCG 9, UCG 11 dan UCG 12. Sebaran titik pengeboran dan penampang pengeboran dapat dilihat pada Gambar 4.

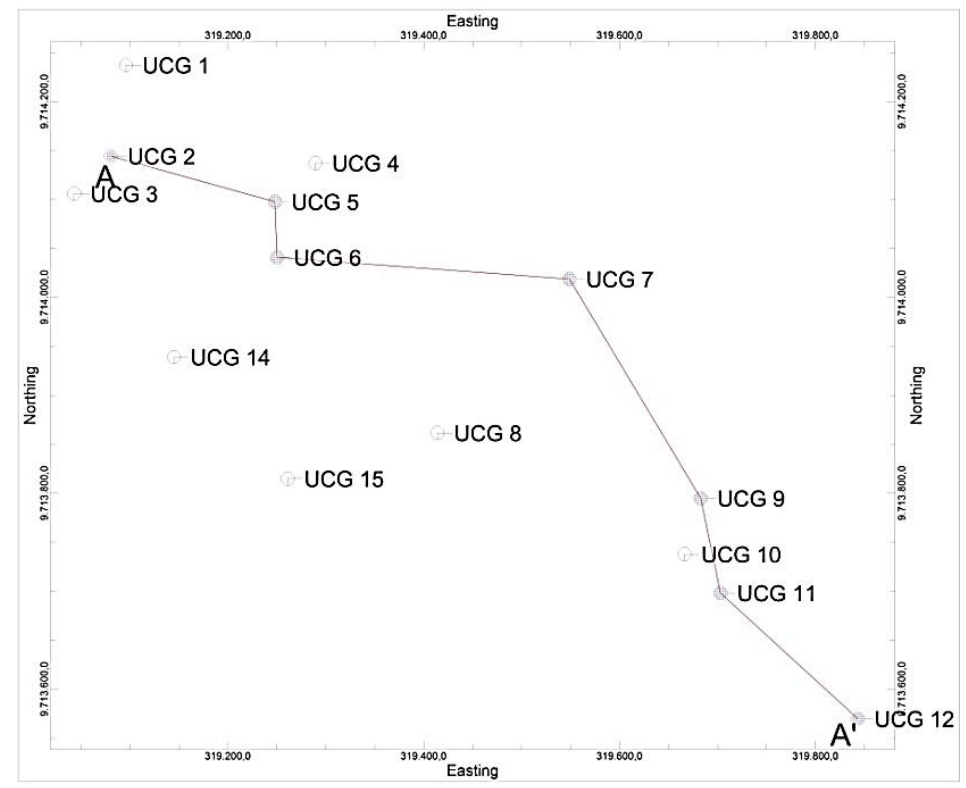

Gambar 4. Peta lokasi pengeboran dan lintasan penampang logbor 


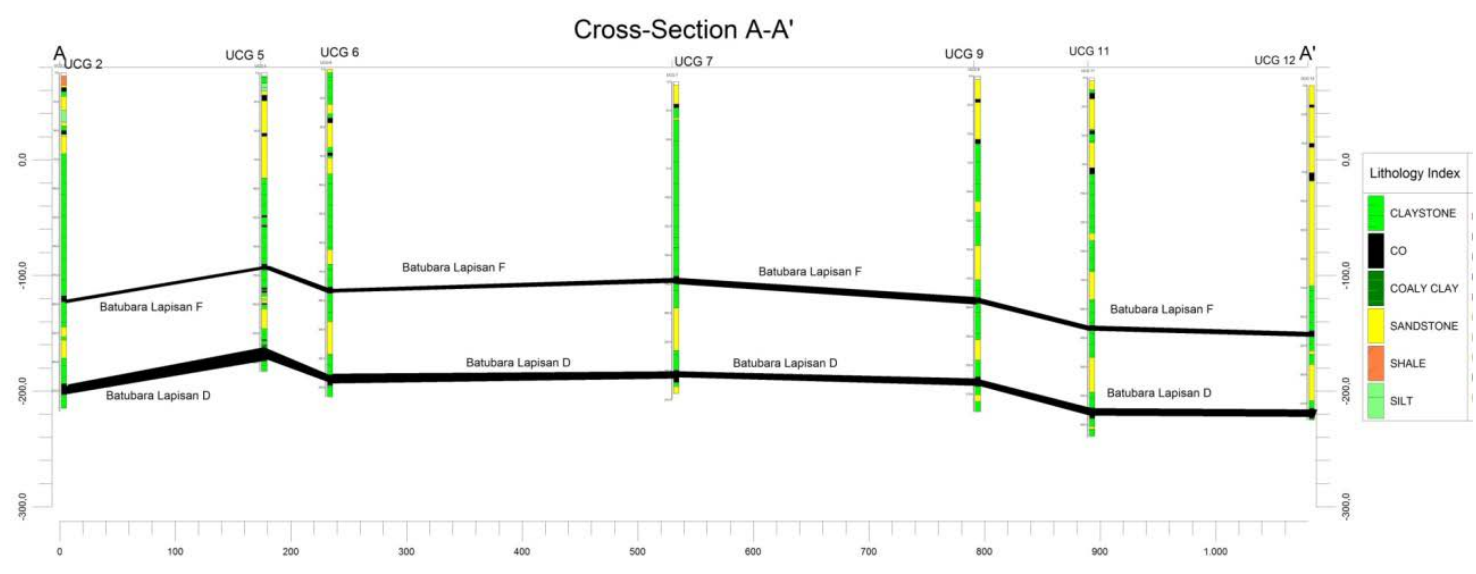

Gambar 5. Penampang logbor dan koralasi batubara UCG2, UCG5, UCG 6, UCG 7, UCG 9, UCG 11, UCG 12

\section{HASIL DAN PEMBAHASAN}

Secara mikroskopis bahan-bahan organik pembentuk batubara disebut maseral, analog dengan mineral dalam batuan. Istilah ini pada mulanya diperkenalkan oleh Stopes (1935) untuk menunjukkan material terkecil penyusun batubara yang hanya dapat diamati di bawah mikroskop (Stach $d k k ., 1982)$.

Maseral dalam batubara dapat dikelompokkan dalam 3 grup utama, yaitu vitrinit, liptinit dan inertinit. Pengelompokan ini didasarkan pada bentuk, morfologi, ukuran, relief, struktur dalam, komposisi kimia, warna pantulan, intensitas refleksi, dan tingkat pembatubaraannya.

Dalam penelitian ini pembagian grup maseral dan subgrup maseral yang digunakan mengacu pada International Committee for Coal Petrology (1963) dan Australian Standard (1986).

Maseral tersebut dapat digunakan untuk menentukan lingkungan pengendapan batubara melalui analisis komposisi maseral berdasarkan model Diessel (1986), dan Calder, Gibling dan Mukhopadhyay (1991) yang telah diaplikasikan di beberapa lapangan batubara di dunia.

Berdasarkan penelitian terdahulu, lingkungan pengendapan batubara pada Formasi Muara Enim Cekungan Sumatera Selatan umumnya diinterpretasi dari percontoh batubara yang berasal dari daerah Muara Enim/Bukit Asam yang merupakan bagian dari Subcekungan
Palembang Bagian Selatan, Cekungan Sumatera Selatan. Dari hasil penelitian didapatkan bahwa lingkungan pengendapan batubara di daerah ini berada pada daerah lembah aluvial dan delta (Santoso, 2015), sementara penelitian lain yang juga dilakukan dari percontoh Lapisan Batubara D dan E yang posisi endapannya berada jauh lebih dalam di Tambang Air Laya-Bukit Asam menginterpretasikan bahwa lingkungan pengendapan batubara berada pada upper delta plain (Purnama dan Ningrum, 2012).

Syufra, Ibrahim dan Fatimah (2000) mengkaji batubara Formasi Muara Enim daerah Subcekungan Palembang Tengah, tepatnya di daerah Sekayu dan menyimpulkan bahwa batubara terbentuk di lingkungan pengendapan fluvial sampai delta. Suryana (2001) juga meneliti batubara di subcekungan ini di daerah Sungai Pinang dan menyimpulkan batubara diendapkan di lingkungan delta.

Permana dan Panggabean (2011) telah mengkaji lingkungan pengendapan batubara Formasi Muara Enim pada Subcekungan Palembang Bagian Tengah, Cekungan Sumatera Selatan dari percontoh batubara daerah Sarolangun, didapatkan bahwa daerah penelitian merupakan daerah lingkungan pengendapan upper delta plain dan fluvial. Walaupun demikian masih belum banyak penelitian terhadap batubara di Subcekungan Palembang Tengah, terutama di daerah Blok Suban Burung, yang letaknya cukup jauh dari daerah penelitian peneliti terdahulu. Penelitian ini berupaya dapat memberikan pengayaan terhadap kondisi lingkungan pengendapan 
batubara di daerah Subcekungan Palembang Bagian Tengah, Cekungan Sumatera Selatan.

Hasil analisis maseral 7 percontoh yang diuji dari lapisan batubara D menunjukkan bahwa komposisi maseral yang mempunyai kemiripan dengan vitrinit adalah grup maseral yang paling dominan $(61-93.4 \%$, rata-rata $71 \%)$, sedangkan maseral lain yang ditemukan dalam jumlah kecil adalah inertinit (4-30\%, rata-rata $17,6 \%)$ dan liptinit $(1-8 \%$, rata-rata $5.4 \%$ ) (Gambar 6).

\section{Grup Maseral Vitrinit}

Komposisi vitrinit didominasi oleh telovitrinit $(0,6-11 \%$, rata-rata $4,2 \%)$, diikuti oleh detrovitrinit $(49-89,4 \%$, rata-rata $64 \%)$ dan gelovitrinit $(0-1,6 \%$, rata-rata 0,43\%) (Gambar 7; Gambar 8 contoh foto vitrinit).

Telovitrinit didominasi oleh maseral telokolinit dengan rata-rata 4,2\%. Maseral telokolinit adalah sisa-sisa jaringan tumbuhan yang berasal dari batang, ranting, daun dan akar berbentuk fragmen-fragmen besar yang tergelifikasi lemah dan langsung terawetkan ketika akumulasi gambut berlangsung (Falcon dan Snyman, 1986). Rendahnya kandungan telokolinit pada hampir seluruh percontoh batubara menandakan bahwa material pembentuk Lapisan Batubara D telah mengalami gelifikasi secara intensif (kuat) dan terawetkan dalam kondisi gambut yang lembab tergenangi oleh air.

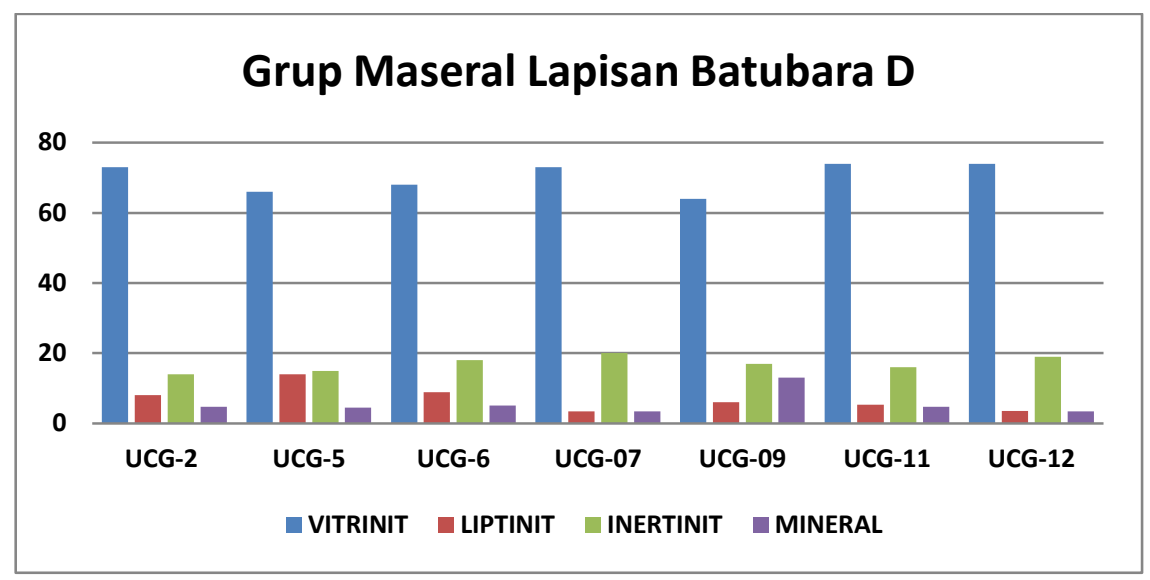

Gambar 6. Komposisi grup maseral Lapisan Batubara D

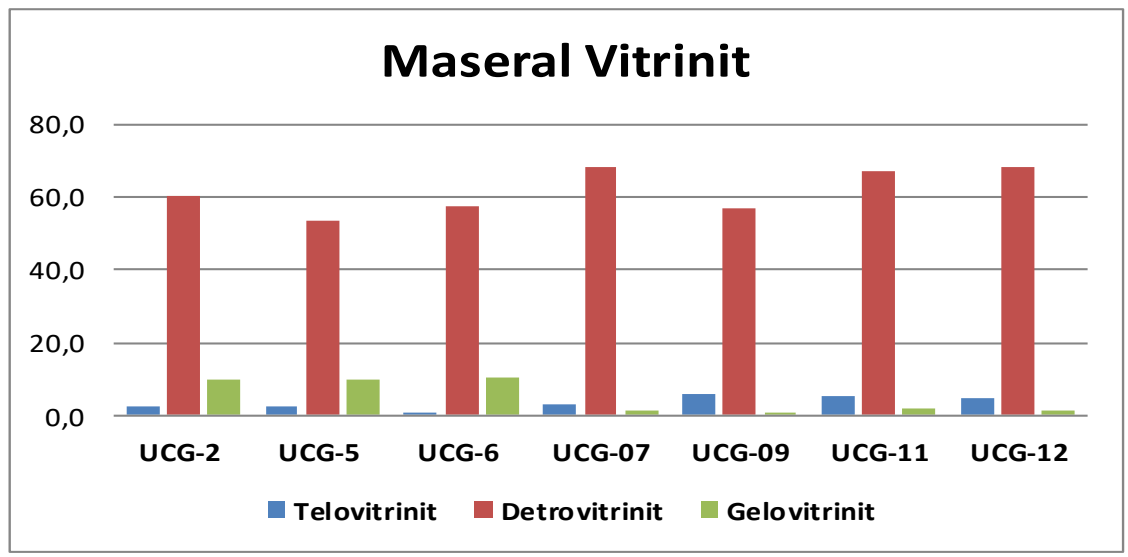

Gambar 7. Komposisi maseral vitrinit Lapisan Batubara D 

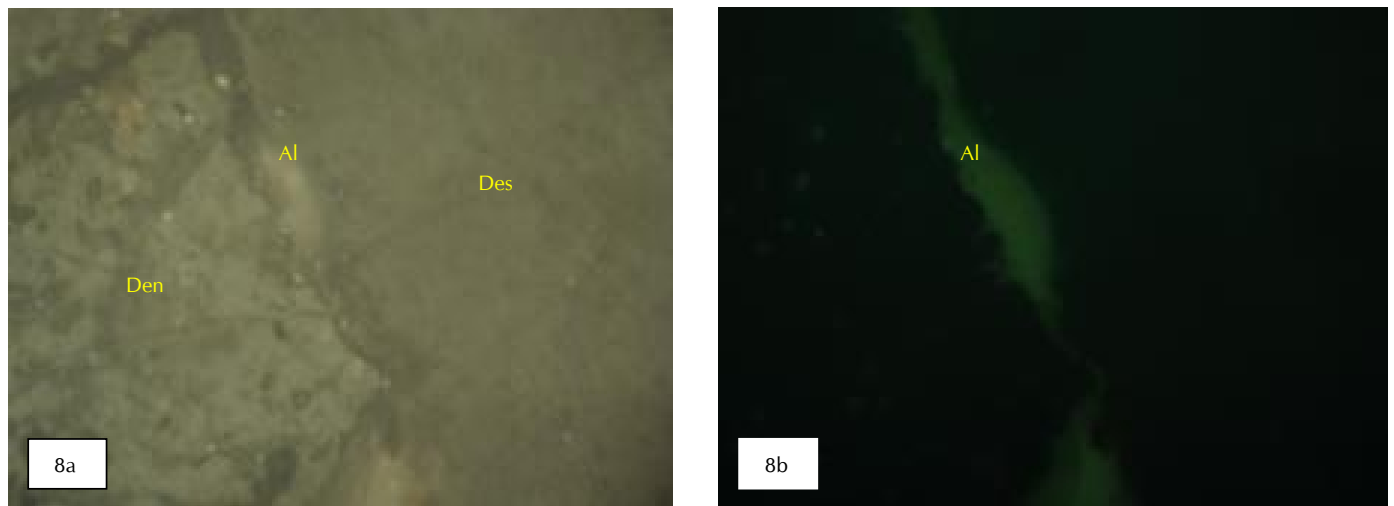

8.a Dominasi maseral vitrinit (densinit dan desmokolinit) sebagai matriks dalam batubara terdapat maseral alginit, lapisan batubara $\mathrm{D}, \mathrm{Rv} \max =0,33$, lebar $=0,22 \mathrm{~mm}$, sinar pantul

8.b Sama seperti 8.a, tetapi menggunakan sinar flouresen

Gambar 8. Fotomikro kelompok maseral vitrinit Lapisan Batubara D, Blok Suban Burung

Detrovitrinit didominasi oleh maseral densinit dengan rata-rata $8,5 \%$. Selain itu, terdapat juga maseral desmokolinit dengan rata-rata $62 \%$. Maseral densinit adalah komponen yang berasal dari tumbuhan perdu dan kayu yang mudah terdekomposisi dengan tingkat gelifikasi yang masih rendah (Teichmuller dan Teichmuller, 1982). Sementara itu, desmokolinit berasal dari susunan sisa-sisa tumbuhan yang berasal dari jaringan tumbuhan yang terurai menjadi butiran halus, baik secara in-situ maupun selama transportasi ke tempat pengendapan (Falcon dan Snyman, 1986). Tingginya nilai densinit dan desmokolinit sebagai tanda proses gelifikasi cukup kuat akibat suplai air, sehingga lokasi rawa tetap terjaga lembab/basah. Gelovitrinit mutlak didominasi oleh maseral korpogelinit dengan rata-rata 4\% (Gambar 9). Hal ini mengindikasikan bahwa proses gelifikasi pada Lapisan Batubara D cukup kuat.

\section{Grup Maseral Liptinit}

Grup maseral liptinit Lapisan Batubara D didominasi oleh maseral suberinit (rata-rata $2.9 \%$ ), resinit (rata-rata 2,9\%), alginit (rata-rata $1,2 \%$ ), kutinit (rata-rata 2,4\%), dan sporinit (rata-rata 0,8\%) (Gambar 10; Gambar 11 contoh foto liptinit). Rendahnya kandungan liptinit membuktikan bahwa batubara terbentuk dari tumbuhan berkayu secara signifikan

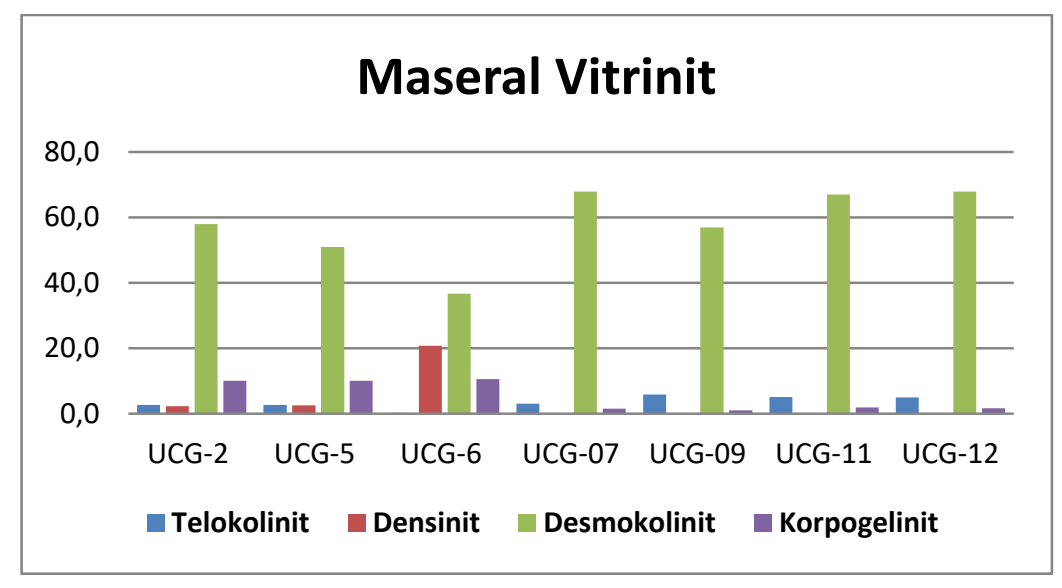

Gambar 9. Komposisi subkelompok maseral vitrinit Lapisan Batubara D 


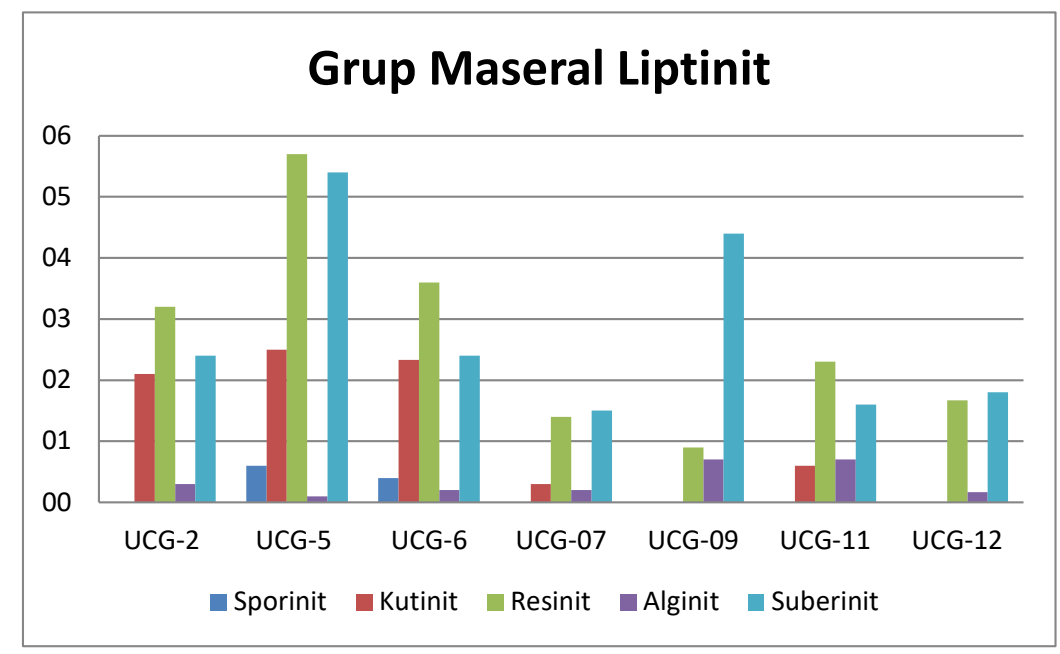

Gambar 10. Komposisi maseral liptinit lapisan batubara D
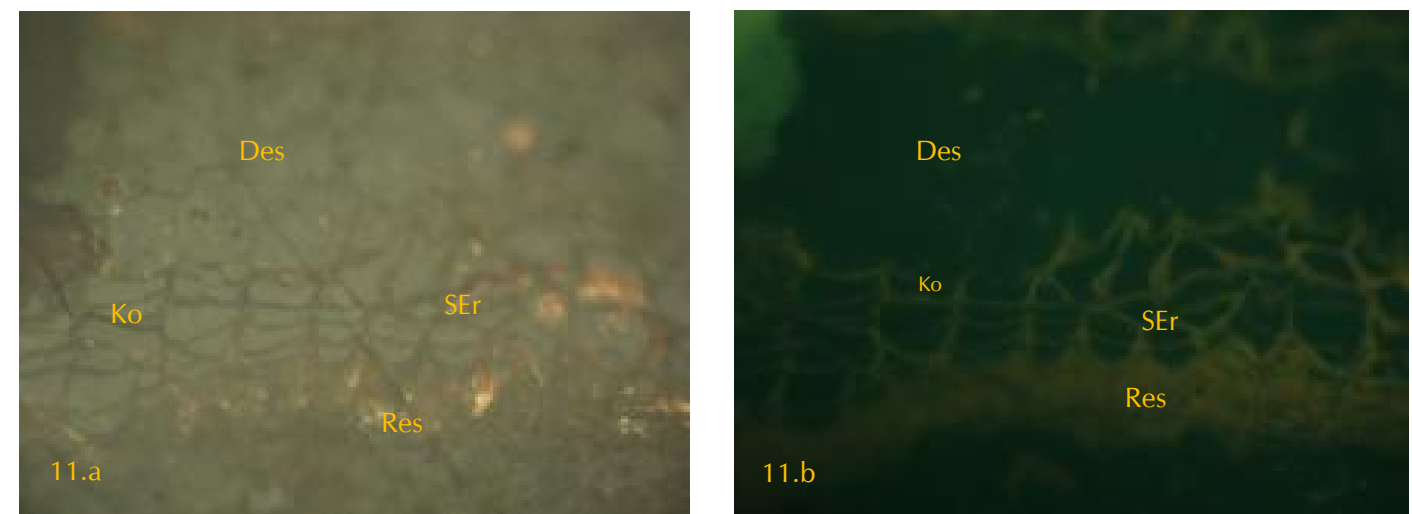

11.a Maseral liptinit (suberinit) berasosiasi dengan korpokolinit dan desmokolinit, Lapisan Batubara $\mathrm{D}, \mathrm{Rv} \max =$ $0,39 \%$, lebar $=0,22 \mathrm{~mm}$, sinar pantul

11.b Sama seperti 11.a, tetapi menggunakan sinar flouresen

Gambar 11. Fotomikro kelompok maseral liptinit Lapisan Batubara D, Blok Suban Burung

\section{Grup Maseral Inertinit}

Grup maseral inertinit Lapisan Batubara D terdiri dari fusinit (rata-rata $4,7 \%$ ), semifusinit (rata-rata 4,6\%), sklerotinit (rata-rata 5,9\%), inertodetrinit (rata-rata 6,7\%) (Gambar 12; Gambar 13 contoh foto inertinit). Maseral inertinit merupakan komponen yang teroksidasi karena berkurangnya kelembaban gambut. Kandungan maseral inertinit yang relatif sedang menunjukkan batubara berasal dari lingkungan pengendapan yang basah dan tingkat oksidasi yang menengah (Stach $d k k$., 1982).

Komposisi maseral dapat mencerminkan rumpun tumbuhan pembentuk rawa gambut. Maseral yang diinterpretasi berasal dari tumbuhan kayu adalah telokolinit, fusinit, semifusinit, suberinit dan resinit. Sementara itu, maseral yang diinterpretasikan berasal dari tumbuhan perdu adalah desmokolinit, densinit, inertodetrinit, sporinit, kutinit, dan alginit.

Komposisi maseral Lapisan Batubara D memperlihatkan bahwa pembentuk maseral lebih didominasi oleh tumbuhan perdu daripada tumbuhan kayu (Gambar 14). Hal ini mengindikasikan bahwa kemungkinan kondisi rawa gambut dalam keadaan rheotrophy (kaya makanan), karena sirkulasi mengandalkan air hujan dan air tanah, sehingga kelembaban gambut terjaga. Adapun variasi kandungan tumbuhan perdu kemungkinan disebabkan oleh turun-naiknya muka air tanah. 


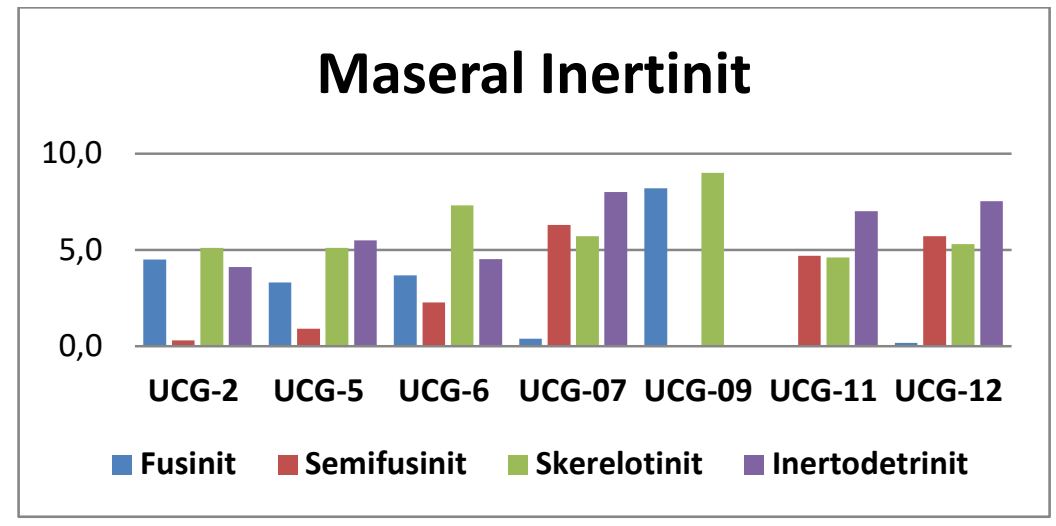

Gambar 12. Komposisi maseral inertinit lapisan batubara D
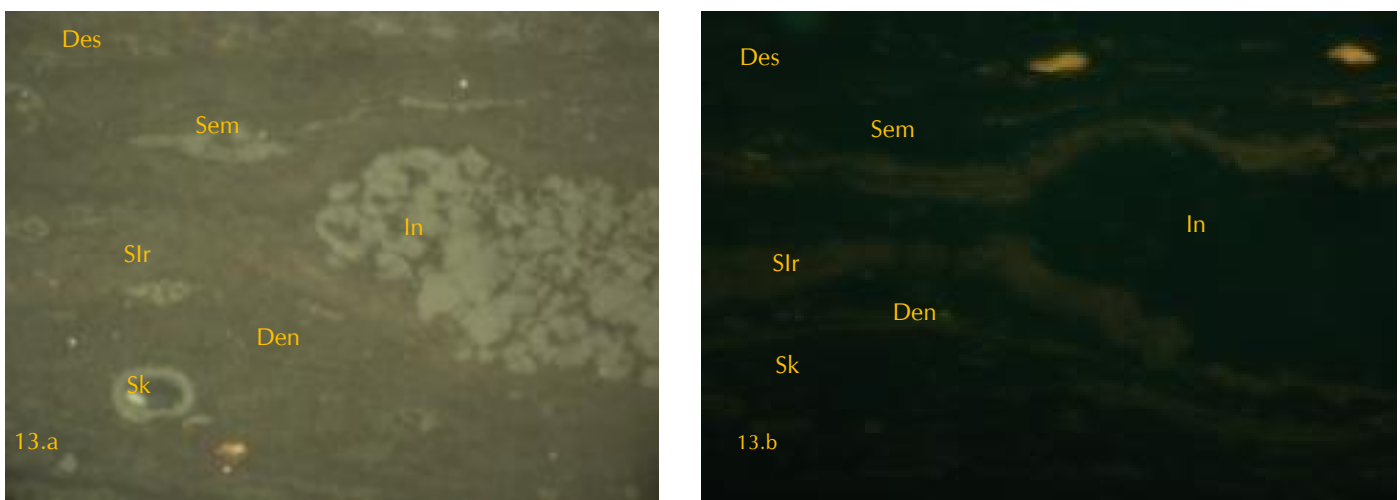

13a Maseral inertinit (inertodetrinit dan semifusinit) berasosiasi dengan sklerotinit, suberinit, desmokolinit dan densinit, Lapisan Batubara D, Rv $\max =0,34 \%$, lebar $=0,22 \mathrm{~mm}$, sinar pantul

13.b Sama seperti 13.a, tetapi menggunakan sinar flouresen

Gambar 13. Fotomikro kelompok maseral inertinit Lapisan Batubara D, Blok Suban Burung

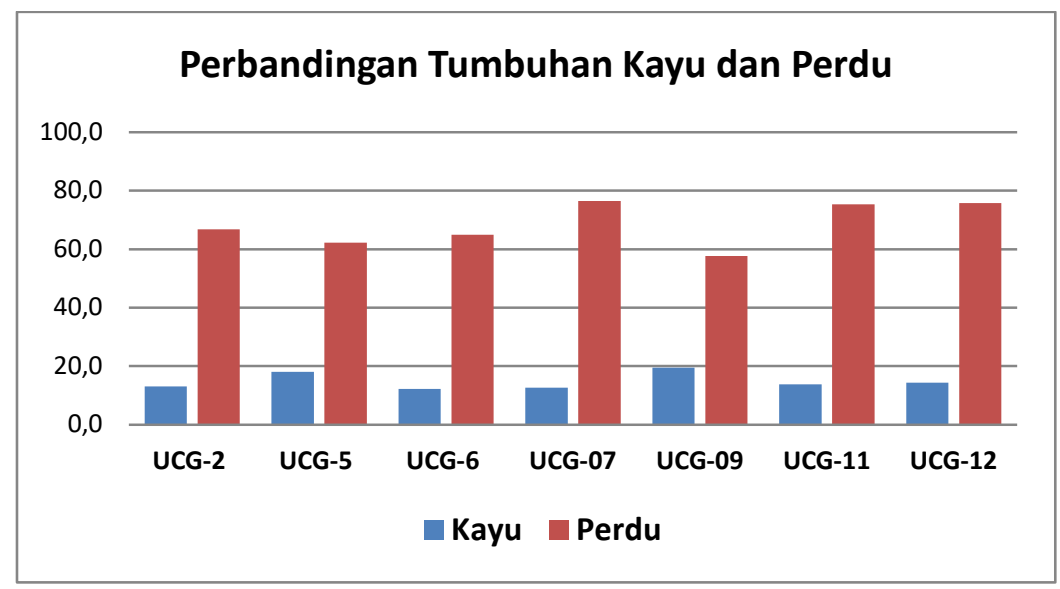

Gambar 14. Perbandingan maseral asal tumbuhan kayu dan tumbuhan perdu pada Lapisan Batubara D 


\section{Kandungan Mineral}

Kandungan mineral Lapisan Batubara D yang teramati adalah pirit dan lempung. Komponen terbesar kandungan mineral adalah pirit (ratarata $4,8 \%$ ) dan diikuti oleh lempung (rata-rata 2,8\%), seperti terlihat pada Gambar 15 dan Gambar 16 (Gambar 16 contoh fotomineral). Adanya variasi kandungan mineral dapat diakibatkan oleh naik-turunnya muka air pada rawa gambut secara bergantian yang disebabkan oleh tidak stabilnya kondisi cekungan atau terjadi banjir dari curah hujan yang cukup tinggi.

\section{Analisis Reflektansi Vitrinit}

Dari grafik data nilai reflektansi vitrinit maksimum rata-rata (Rvmax\%) pada 7 lokasi pengambilan percontoh inti bor Lapisan Batubara D didapatkan bahwa batubara ini hanya mempunyai 1 rentang Rvmax\%, yaitu
0,25-38\%, yang menggolongkan ke dalam jenis lignit sampai dengan subbituminus.

Berdasarkan histogram, nilai reflektansi Lapisan Batubara D yang mempunyai kisaran yang dekat dengan bentuk histogram relatif homogen (Gambar 17), mengindikasikan bahwa pada daerah ini tidak dipengaruhi oleh adanya faktor luar yang berupa gejala struktur geologi, baik itu intrusi ataupun sesar.

\section{Interpretasi Fasies dan Lingkungan Pengendapan Batubara}

Penentuan lingkungan pengendapan batubara yang dilakukan menggunakan analisis komposisi maseral menurut Diessel (1986) dengan menggunakan suatu perhitungan yang dikenal sebagai GI (Gelification Index) dan TPI (Tissue Preservation Index) yang dikombinasikan dengan perhitungan nilai GWI (Ground Water Index) dan VI (Vegetation Index) dari Calder, Gibling dan Mukhopadhyay (1991).

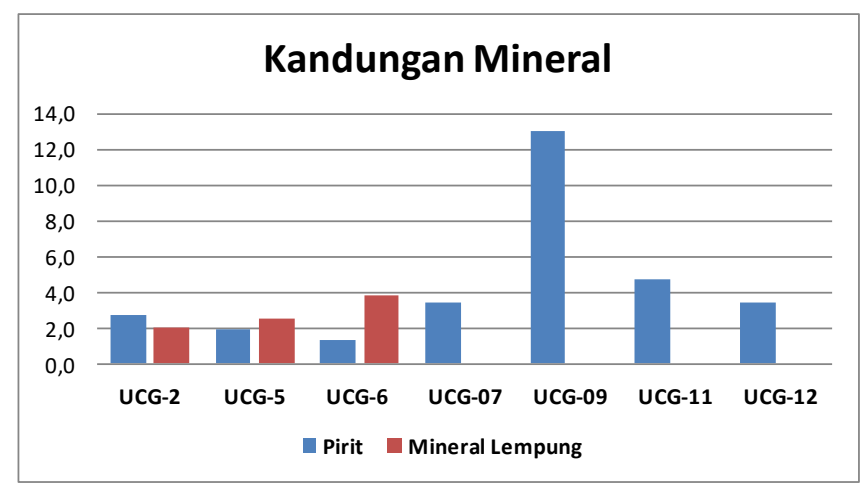

Gambar 15. Komposisi mineral Lapisan Batubara D
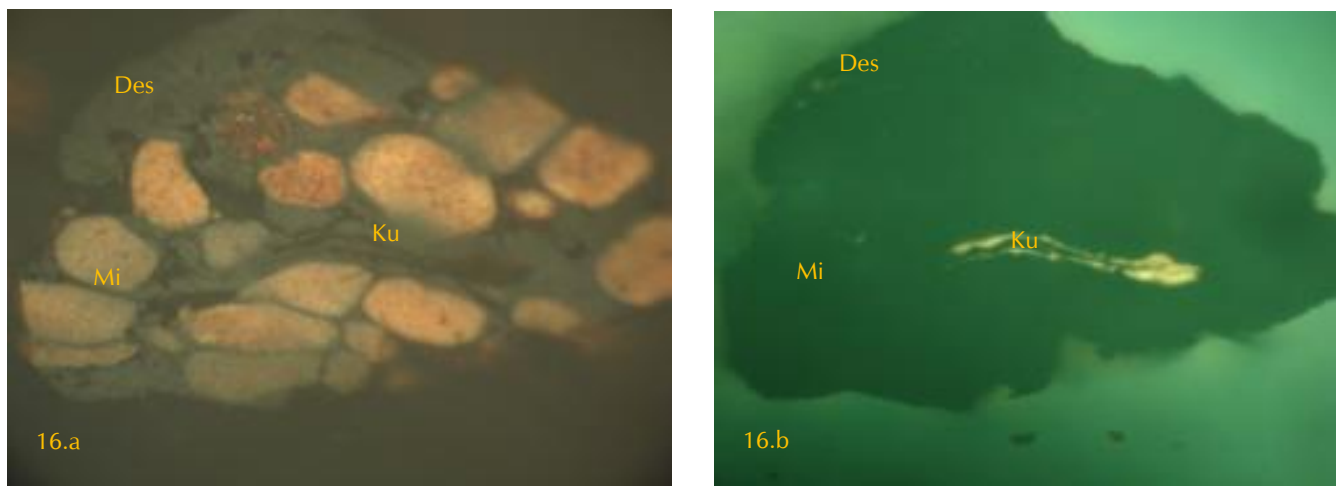

16.a Kandungan Mineral (mineral sulfida) berasosiasi dengan kutinit dan desmokolinit, Lapisan Batubara D, Rv $\max =0,38 \%$, lebar $=0,22 \mathrm{~mm}$, sinar pantul

16.b Sama seperti 16.a, tetapi menggunakan sinar flouresen

Gambar 16. Fotomikro kandungan mineral Lapisan Batubara D, Blok Suban Burung 


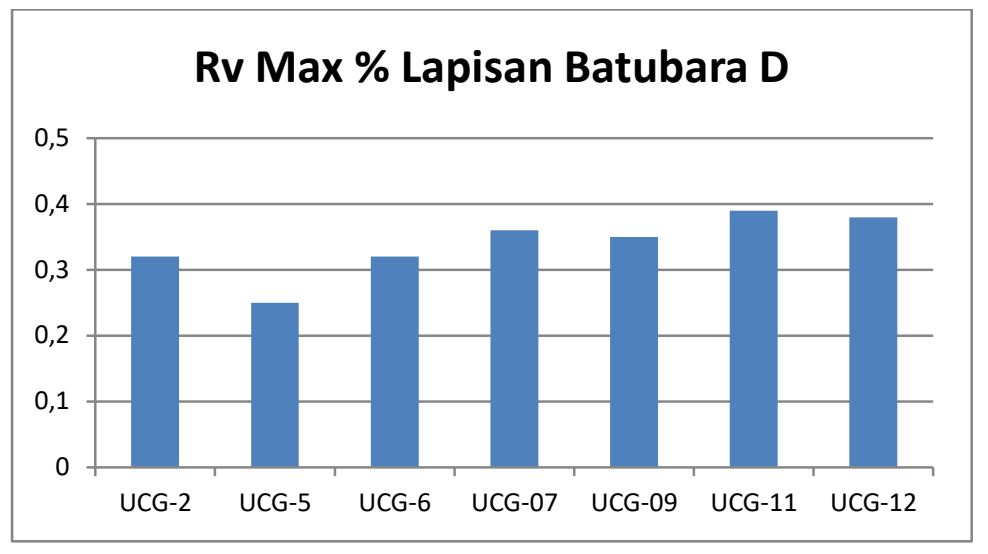

Gambar 17. Histogram reflektansi vitrinit Lapisan Batubara D

\section{Interpretasi Fasies dan Lingkungan Batubara Dengan Metode TPI-GI}

Interpretasi lingkungan pengendapan batubara dengan metode TPI (Tissue Preservation Index) dan GI (Gelification Index) atau TPI-GI telah digunakan oleh beberapa peneliti dalam menentukan fasies dan lingkungan pengendapan batubara di Indonesia, seperti Permana dan Panggabean (2011) mengenai interpretasi lingkungan pengendapan batubara Formasi Muara Enim di Daerah Sekitar Sarolangun, Provinsi Jambi. Kemudian Heryanto (2009) mengamati lingkungan pengendapan batubara Formasi Tanjung, Provinsi Kalimantan Selatan, serta Kusnama dan Panggabean (2009) meneliti lingkungan pengendapan batubara Formasi Talang Akar di Lampung. Widiyanto $d k k$. (2014) menginterpretasi lingkungan pengendapan batubara daerah Balikpapan, Kalimantan Timur.

Dari hasil perhitungan terhadap nilai TPI pada Lapisan Batubara D, Formasi Muara Enim di Blok Suban Burung, didapatkan bahwa rata-rata nilai TPI tergolong rendah $(<1 \%)$. Rendahnya nilai TPI ini menunjukkan rendahnya persentase kehadiran tumbuh-tumbuhan kayu (dalam hal ini ditunjukkan sedikitnya komposisi maseral telokolinit pada seluruh lapisan batubara tersebut). Hal ini juga dapat menunjukkan buruknya pengawetan jaringan tumbuhan.

Sedangkan dari hasil perhitungan GI Lapisan Batubara D memiliki nilai yang bervariasi medium (5-10). Nilai GI menunjukkan tingkat oksidasi yang berlangsung selama proses pengendapan dan pembentukan batubara.
Nilai Gl yang tergolong bervariasi medium mengindikasikan naik-turunnya muka air tanah dan tingkat oksidasi pada daerah ini terjadi tidak dominan dan berlangsung tidak intensif. Secara Lengkap ringkasan nilai TPI dan GI dapat dilihat pada Tabel 2.

Tabel 2. Hasil perhitungan nilai TPI-GI dan GWIVI

\begin{tabular}{cccccc}
\hline No & Lapisan D & TPI & Gl & GWI & VI \\
\hline 1 & UCG 02 & 0,12 & 9,79 & 0,24 & 0,20 \\
2 & UCG 05 & 0,12 & 9,79 & 0,27 & 0,30 \\
3 & UCG 06 & 0,15 & 6,65 & 0,27 & 0,19 \\
4 & UCG 07 & 0,13 & 5,5 & 0,07 & 0,17 \\
5 & UCG 09 & 0,25 & 9,08 & 0,22 & 0,34 \\
6 & UCG 11 & 0,14 & 9,78 & 0,10 & 0,19 \\
7 & UCG 12 & 0,17 & 6,09 & 0,07 & 0,19 \\
\hline
\end{tabular}

Berdasarkan hasil interpretasi nilai TPI-GI pada diagram Diessel, disimpulkan bahwa lingkungan pengendapan batubara lapisan D berada pada lingkungan pengendapan limnik seperti pada Gambar 18.

Limnik adalah lahan basah subakuatik, rawa air tawar yang tidak terpengaruh oleh air laut, jika daerah ini terletak dekat dengan laut, namun dipisahkan oleh kedalaman atau penghalang/tanggul (barrier) yang bersifat tidak lulus air (impermeable). Di daerah ini, tumbuhan umumnya berupa rerumputan, lumut dan tumbuhan tingkat rendah, serta sangat jarang ditumbuhi oleh tumbuhan pepohonan. Daerah limnik tidak terpengaruh oleh air laut, terlihat dengan sedikitnya komposisi sulfur dalam batubara lapisan D, terlebih minimnya jenis sulfur piritik dan 
litotipe batubara lapisan D relatif kusam. Kondisi tersebut sangat relevan dengan komposisi maseralnya, yakni pada seluruh lapisan batubara memiliki persentase vitrinit yang tinggi, komposisi inertinit yang tergolong rendah-sedang, dengan vitrinit yang berupa detritus lebih banyak daripada vitrinit berstruktur. Kondisi daerah ini mempunyai komposisi vitrinit yang tidak berstruktur lebih banyak daripada vitrinit yang berstruktur. Hal ini juga dapat ditunjukkan dengan sangat minimnya telovitrinit dan tingginya persentase detrovitrinit bila dibandingkan dengan jenis vitrinit lainnya. Di daerah ini, tumbuhan yang ada dapat berasal dari luar zona yang kemudian mengalami pengangkutan. Selama transportasi, tumbuhan-tumbuhan tersebut mengalami pembusukan pada bagian atasnya setelah melalui air yang teroksidasi. Kondisi demikian relevan dengan hadirnya komposisi maseral inertinit yang tergolong melimpah.

\section{Analisis Fasies dan Lingkungan Berdasarkan Nilai GWI dan VI}

Interpretasi lingkungan pengendapan batubara dengan metode GWI (Ground Water Index) dan VI (Vegetation Index) atau GWI-VI, dapat juga digunakan dalam menginterpretasi lingkungan pengendapan batubara, seperti dilakukan oleh Pratama dan Amijaya (2015) dalam menginterpretasikan lingkungan pengendapan batubara Formasi Warukin. Kajian peneliti lain terkait interpretasi lingkungan pengendapan batubara dengan metode GWI-VI adalah Purnama dan Ningrum (2012), yang menginterpretasi lingkungan pengendapan batubara Formasi Muara Enim di daerah Tanjung Enim dengan metode tersebut.

Dari hasil perhitungan nilai VI pada maseral Lapisan Batubara D, Formasi Muara Enim di Blok Suban Burung menunjukkan hasil yang kecil $(<1)$. Hal ini menandakan bahwa komposisi maseral berasal dari tumbuhan kayu lebih kecil dibandingkan tumbuhan perdu, sedangkan untuk nilai GWI yang didapat juga menunjukkan angka yang rendah $(<1)$. Hal ini mengindikasikan bahwa maseral tidak tergelifikasi secara intensif yang disebabkan gambut terbentuk pada kondisi yang cenderung asam ( $\mathrm{pH}$ rendah). Tipe gambut untuk Lapisan Batubara D setelah diplot pada diagram Calder, Gibling dan Mukhopadhyay (1991) menunjukkan bahwa semua percontoh batubara cenderung berada pada zona bog-ombrotrophic (Gambar 19), yang menggambarkan kondisi rawa gambut tergantung pada air hujan, ber-pH kecil dan miskin oksigen, sehingga aktivitas mikroorganisme kecil dan terhambatnya penghancuran sisa makanan.

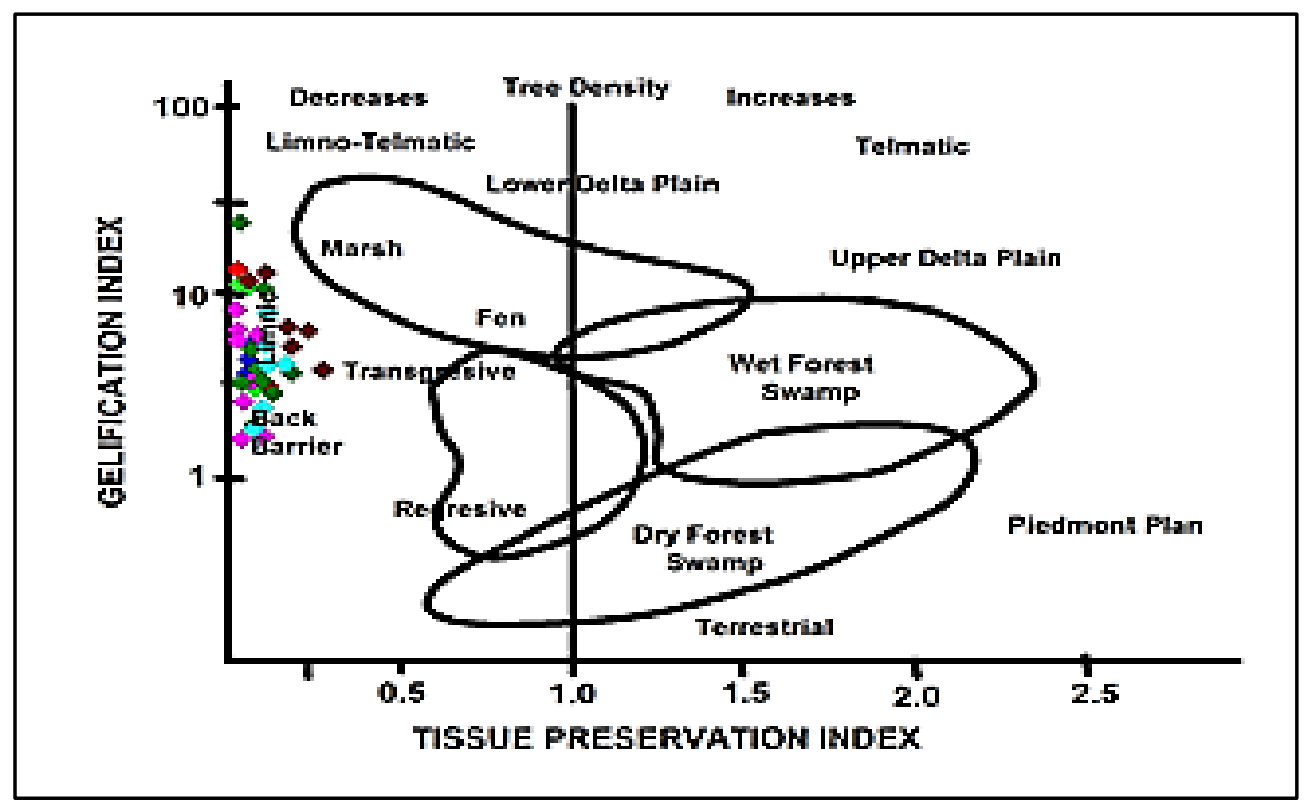

Gambar 18. Plot nilai TPI-GI Lapisan batubara D pada diagram Diessel (1986) 


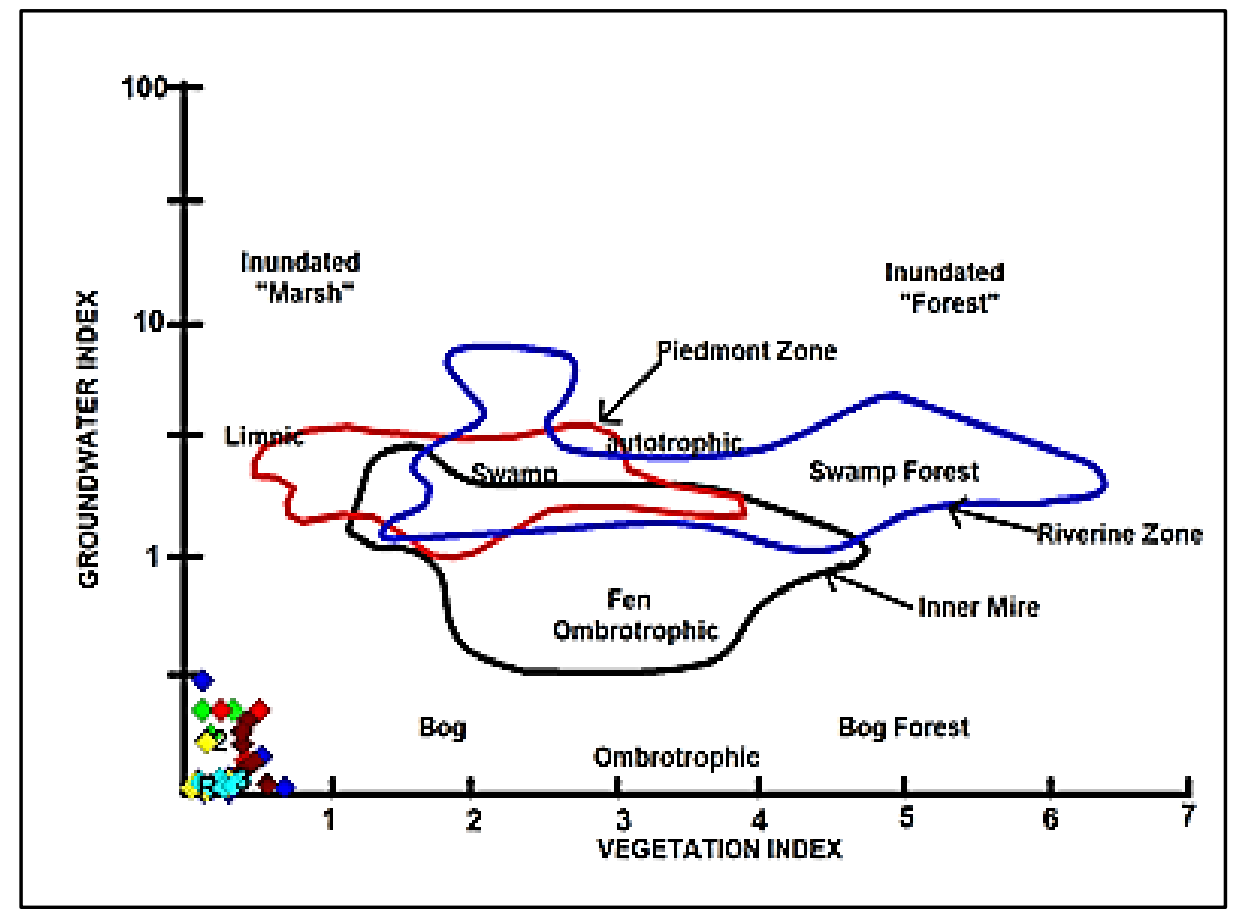

Gambar 19. Nilai VI-GWI Lapisan Batubara D pada diagram Calder, Gibling dan Mukhopadhyay (1991)

Gambut yang terbentuk pada lingkungan bogombrotrombhic terbentuk dalam kondisi asam dengan suplai makanan yang rendah (oligotrophy). Daerah ini merupakan daerah yang ditumbuhi oleh vegetasi tingkat rendah (seperti lumut, rerumputan dan tanaman merambat) yang miskin akan nutrisi makanan dan banyak tergantung pada air hujan, sehingga $\mathrm{pH}$ kecil (kondisi asam) dan miskin oksigen. Akibatnya, aktivitas mikroorganisme kecil dan terhambatnya penghancuran sisa makanan. Komposisi vegetasi yang merupakan tumbuhan dengan tingkat rendah, relevan dengan komposisi maseralnya, dengan maseral yang dianalisis berasal dari tumbuhan kayu adalah telovitrinit, fusinit, semifusinit, telogelinit, suberinit dan resinit memiliki persentase yang lebih rendah. Sementara maseral yang diinterpretasikan berasal dari tumbuhan tingkat rendah adalah detrovitrinit (terutama desmokolinit), inertodetrinit, sporinit, kutinit, liptodetrinit dan alginit mempunyai persentase yang lebih tinggi.

Kondisi gambut terbentuk pada saat bogombrotrombhic, maka dapat diketahui bahwa pembentukan batubara pada daerah ini berada pada kondisi high moor. Pada kondisi ini, batubara terbentuk di atas permukaan air tanah dengan hanya mengandalkan nutrisi dan kelembaban yang berasal dari air hujan saja. Batubara daerah ini mempunyai tingkat gelifikasi yang tinggi. Hal ini menunjukkan bahwa curah hujan cukup tinggi pada saat proses penggambutan. Kondisi ini bisa mencapai beberapa meter dari permukaan tanah dengan bentuk yang cembung.

\section{Pengaruh Fasies dan Lingkungan Pengendapan Terhadap Komposisi Sulfur}

Anggayana dan Widayat (2007) menyebutkan bahwa ada keterkaitan antara lingkungan pengendapan dan kandungan sulfur dalam batubara di Berau Kalimantan Timur, serupa dengan tulisan Riswandi (2008) yang menyatakan bahwa kualitas batubara sangat terpengaruh oleh lingkungan tempat batubara tersebut diendapkan.

Salah satu parameter penting penentu kualitas batubara adalah kandungan sulfur. Kondisi keasamaan $(\mathrm{pH})$, tingkat oksidasi, aktivitas bakteri dan pengaruh air laut, berpengaruh pada lingkungan pengendapan dalam menyebarkan kuantitas komposisi sulfurnya. Lingkungan limnik biasanya memiliki $\mathrm{pH}$ yang tergolong asam $(4,5-7 \mathrm{pH})$ dan umumnya sulfat yang terlarut sangat rendah $(<40 \mathrm{ppm})$. Sulfat terlarut juga rendah, sehingga sulfur yang 
terbentuk sedikit karena aktivitas bakteri juga rendah. Dengan demikian, jumlah sulfur yang dihasilkan tergantung pada kondisi $\mathrm{pH}$, oksigen, konsentrasi sulfat dan untuk pirit khususnya perlu kehadiran ion Fe dan aktivitas bakteri.

Rendahnya nilai sulfur seperti yang terlihat pada Tabel 3, dikarenakan lingkungan pengendapan yang berada pada lingkungan limnik juga dapat diakibatkan karena rendahnya nutrisi yang menyuplai saat proses penggambutan. Hal ini ditunjukkan oleh diagram GWI dan VI yang menyatakan bahwa semua lapisan batubara merupakan batubara yang berada pada daerah bog-ombrotrophic, yang miskin makanan dan hanya mendapat suplai nutrisi makanan dari air hujan. Dari 7 lokasi percontoh Lapisan Batubara D tidak menunjukkan adanya suplai air laut. Hal ini ditunjukkan dengan rendahnya nilai total sulfur dan rendahnya sulfur piritik. Apabila batubara pada proses penggambutan dan pembentukannya banyak dipengaruhi oleh air laut, maka total sulfurnya akan tinggi ( $>5 \%$ ) dengan jenis sulfur yang mendominasi adalah sulfur piritik.

Tabel 3. Kandungan sulfur dan bentuk sulfur batubara lapisan D

\begin{tabular}{lcccc}
\hline $\begin{array}{l}\text { Kandungan } \\
\text { Sulfur }\end{array}$ & UCG 7 & UCG 9 & UCG 11 & UCG 12 \\
\hline Total & 0,21 & 0,202 & 0,286 & 0,318 \\
Sulfat & 0,019 & 0,046 & 0,027 & 0,021 \\
Piritik & 0,07 & 0,026 & 0,089 & 0,047 \\
Organik & 0,12 & 0,13 & 0,17 & 0,25 \\
\hline
\end{tabular}

\section{KESIMPULAN}

Analisis petrografi Lapisan Batubara D menunjukkan kandungan nilai TPI rendah dan GI medium, sehingga dapat diinterpretasi pada diagram Diessel bahwa batubara tersebut diendapkan pada lingkungan pengendapan limnik, yang berada pada lahan basah sub-akuatik yang tidak terpengaruh oleh air laut. Selain itu kondisi gambut juga diinterpretasi dari nilai GWI dan VI pembentuk batubara tersebut yang berada pada bog-ombrotrophic. Hal ini menunjukkan bahwa daerah ini tersusun oleh tumbuhan dengan kelas rendah seperti tanaman lumut, semak, tanaman merambat, dan rerumputan dengan kondisi yang miskin makanan dan bergantung kepada air hujan untuk mendapat suplai makanan. Kondisi lingkungan pengendapan batubara lapisan D sangat relevan terhadap kandungan sulfur yang relatif rendah, karena kondisi gambut bersifat asam, rendah nutrisi dan suplai air terbatas. Dari hasil analisis vitrinit disimpulkan bahwa batubara lapisan D dengan rentang Rvmax\%, antara $0,25-38 \%$, termasuk ke dalam jenis peringkat batubara lignit sampai dengan subbituminus, sehingga sangat cocok untuk digunakan dalam pengembangan gasifikasi batubara bawah tanah (Underground Coal Gasification/UCG).

\section{UCAPAN TERIMA KASIH}

Penulis mengucapkan terima kasih kepada Kepala Pusat Penelitian dan Pengembangan Teknologi Mineral dan Batubara yang telah memberikan dukungan penuh atas terlaksananya kegiatan kelitbangan UCG ini. Ucapan terima kasih juga kami tujukan kepada Prof. Binarko Santoso yang telah membimbing penulisan dan kepada rekan-rekan di Laboratorium Batubara Puslitbang tekMIRA yang telah membantu menganalisis batubara secara cermat. Kepada para pembantu kegiatan kelitbangan di lokasi penelitian, kami juga mengucapkan terima kasih atas upayanya dalam menyelesaikan kegiatan ini.

\section{DAFTAR PUSTAKA}

Amijaya, H. and Littke, R. (2006) "Properties of thermally metamorphosed coal from Tanjung Enim Area, South Sumatra Basin, Indonesia with special reference to the coalification path of macerals," International Journal of Coal Geology, 66(4), pp. 271-295. doi: 10.1016/j.coal.2005.07.008.

Anggayana, K. and Widayat, A. H. (2007) "Interpretasi fasies/lingkungan pengendapan batubara dan variasi sulfur untuk rekomendasi strategi eksplorasi. Kasus: Seam R, daerah Lati, sub-cekungan Berau, cekungan Tarakan," Jurnal Geoaplika, 2(1), pp. 35-52.

ASTM D2798-06 (2006) Standard test method for microscopical determination of the vitrinite reflectance of coal. West Conshohocken: ASTM International. Available at: https://www.astm.org/DATABASE.CART/HIST ORICAL/D2798-06.htm. 
Australian Standard (1986) "Coal - Maceral anlysis." Australia.

Badan Geologi (2016) Ringkasan eksekutif pemutakhiran data dan sumber daya energi. Bandung.

van Bemmelen, R. W. (1949) The geology of Indonesia vol. II: Economic geology. The Hague.

Bhutto, A. W., Bazmi, A. A. and Zahedi, G. (2013) "Underground coal gasification: From fundamentals to applications," Progress in Energy and Combustion Science, 39(1), pp. 189-214. doi: 10.1016/j.pecs.2012.09.004.

Bishop, M. G. (2001) South Sumatera Basin Province, Indonesia: The Lahat/Talang Akarcenozoic total petroleum system. Denver, Colorado. Available at: https://pubs.usgs.gov/of/1999/ofr-990050/OF99-50S/OF99-50S.pdf.

Calder, J. H., Gibling, M. R. and Mukhopadhyay, P. K. (1991) "Peat formation in a Westphalian B Piedmont setting, Cumberland Basin, Nova Scotia: Implications for the maceral-based interpretation of rheotrophic and raised paleomires," Bulletin de la Société Géologique de France, 162(2), pp. 283-298.

De Coster, G. L. (1974) "The geology of central and South Sumatra basin," in Proceedings Indonesian Petroleum Association. 3rd Annual Convention. Jakarta: Indonesian Petroleum Association, pp. 77-110. Available at:

http://archives.datapages.com/data/ipa/data/0 03/003001/77_ipa0030077.htm.

Darman, H. (2000) An Outline of the Geology of Indonesia. Edited by F. H. Sidi. Jakarta: Indonesian Association of Geologists.

Daulay, B., Ningrum, N. S. and Cook, A. C. (2000) "Coalification of Indonesian coal," in Proceedingsof Southeast Asian Coal Geology. Bandung, pp. 85-92.

Diessel, C. F. K. (1986) "The correlation between coal facies and depositional environments. Advances in the Study of the Sydney Basin," in Proc. 20th Symp. University Newcastle, pp. 19-22.

Falcon, R. M. S. and Snyman, C. P. (1986) An introduction to coal petrography: atlas of petrographic constituents in the bituminous coals of Southern Africa. Johannesburg: Geological Society of South Africa.
Friedmann, S. J., Upadhye, R. and Kong, F.-M. (2009) "Prospects for underground coal gasification in carbon-constrained world," Energy Procedia, 1(1), pp. 4551-4557. doi: 10.1016/j.egypro.2009.02.274.

Gafoer, S., Amin, T. C. and Purnomo, J. (2007) Peta geologi lembar Lahat, Sumatera Selatan, skala 1:250.000. Bandung.

van Gorsel, T. J. (1988) "Geological fieldtrip South Sumatera and Bengkulu," in South Sumatra and Bengkulu - 17th Annual Post-Convention Field Trip. Indonesian Petroleum Association.

Heryanto, R. (2009) "Karakteristik dan Lingkungan Pengendapan Batubara Formasi Tanjung di daerah Binuang dan sekitarnya, Kalimantan Selatan," Indonesian Journal on Geoscience, 4(4), pp. 239-252. doi: 10.17014/ijog.v4i4.84.

Imran, M., Kumar, D., Kumar, N., Qayyum, A., Saeed, A. and Bhatti, M. S. (2014) "Environmental concerns of underground coal gasification," Renewable and Sustainable Energy Reviews, 31, pp. 600-610. doi: 10.1016/j.rser.2013.12.024

International Committee for Coal Petrology (1963) International handbook of coal petrography. 2nd ed. Paris: Centre National de la Recherche Scientifique.

Jackson, A. (1961) Oil Exploration a Brief Review With Illustrations From South Sumatra. Bandung: Institut Teknologi Bandung.

Khadse, A., Qayyumi, M., Mahajani, S. and Aghalayam, P. (2007) "Underground coal gasification: A new clean coal utilization technique for India," Energy, 32(11), pp. 20612071. doi: 10.1016/j.energy.2007.04.012.

Koesoemadinata, R. P. (2000) "Tectono-stratigraphic framework of Tertiary coal deposits of Indonesia," in Herudyanto, Sukarjo, Djaelani, E., and Komaruddin (eds.) Proceedings of Southheast Asia Coal Geology. Directorate of Mineral Resources, pp. 8-16.

Kreynin, E. V. (2012) "An analysis of new generation coal gasification projects," International Journal of Mining Science and Technology, 22(4), pp. 509-515. doi: 10.1016/j.ijmst.2012.01.012.

Kusnama, K. and Panggabean, H. (2009) "Karakteristik Batubara dan Batuan Sedimen Pembawanya, Formasi Talangakar, di daerah Lampung Tengah," Indonesian Journal on Geoscience, 4(2), pp. 133-144. doi: 10.17014/ijog.vol4no2.20095. 
Permana, A. K. and Panggabean, H. (2011) "Depositional environmental of the Sarolangun coal, South Sumatera Basin," Journal of Geology and Mineral Resources, 21(4), pp. 225-235. Available at: http://jgsm.geologi.esdm.go.id/index.php/JGS M/article/view/149.

Pratama, D. A. P. and Amijaya, D. H. (2015) "Lingkungan pengendapan batubara formasi warukin berdasarkan analisis petrografi organik di daerah Paringin, cekungan Barito, Kalimantan Selatan," in Proceeding Seminar Ke-8 Akademia-Industry Linkage. Universitas Gadjah Mada, pp. 582-593.

Purnama, A. B. and Ningrum, N. S. (2012) "Petrographic characteristics and depositional environment of coal seam D (Merapi) and $E$ (Keladi), Muara Enim formation, South Sumatera Basin," Indonesian Mining Journal, 15(1), pp. 1-13. Available at: http://jurnal.tekmira.esdm.go.id/index.php/imj /article/view/470.

Riswandi, H. (2008) "Pengaruh lingkungan pengendapan terhadap kualitas batubara daerah Binderang, Lokpaikat, Tapin, Kalimantan Selatan," Jurnal IImiah MTG, 1(2).

Salinita, S. and Purnama, A. B. (2014) "Pengaruh struktur geologi terhadap kualitas batubara lapisan D formasi Muara Enim," Jurnal Teknologi Mineral dan Batubara, 10(2), pp. 91-104.

Santoso, B. (2015) Petrologi batubara Sumatera dan Kalimantan: Jenis, peringkat dan aplikasi. Jakarta: LIPI Press.

Stach, E., Mackowsky, M.-T., Teichmüller, M., Taylor, G. H., Chandra, D. and Teichmüller, R. (1982) Stach's textbook of coal petrology, Book.

Stopes, M. C. (1935) "On the petrology of banded bituminous coals," Fuel, (14), pp. 4-13.

Suárez-Ruiz, I. and Crelling, J. (2008) Applied coal petrology: The role of coal petrology in coal utilization. 1st Editio. Elsivier.
Sumaatmadja, E. R. and Iskandar (2001) Penyelidikan batubara bersistem dalam cekungan Sumatera Selatan, di daerah Nibung dan sekitarnya, Kabupaten Sarolangun, Provinsi Jambi; Kabupaten Batang Harileko dan Musi Rawas, Provinsi Sumatera Selatan.

Suryana, A. (2001) Pengkajian batubara bersistem dalam cekungan Sumatera Selatan di daerah Sungai Pinang dan sekitarnya, Kabupaten Musirawas dan Kabupaten Musi Banyuasin, Provinsi Sumatera Selatan.

Susilawati, R. and Ward, C. R. (2006) "Metamorphism of mineral matter in coal from the Bukit Asam deposit, south Sumatra, Indonesia," International Journal of Coal Geology, 68(3-4), pp. 171-195. doi: 10.1016/j.coal.2006.02.003.

Suwarna, N., Suharsono, S., Gafoer, Amin, T. C., Kusnama and Hermanto, B. (1992) Peta geologi lembar Sarolangun skala 1:250.000. Bandung.

Syufra, I., Ibrahim, D. and Fatimah (2000) "Pengkajian endapan batubara di dalam cekungan Sumatera Selatan, daerah Sekayu, Kabupaten Musi Banyuasin, Provinsi Sumatera Selatan," in Kolokium Hasil Kegiatan Lapangan DIK-S, DSM, pp. 5-1-5-10.

Teichmuller, M. and Teichmuller, R. (1982) "The geological basis of coal formation," in E., S., Mackowsky, M. T., Teichmuller, M., Taylo, G. H., Chandra, D., and Teichmuller, R. (eds.) Stach's textbook of coal petrology. 3rd ed. Gebrüder Borntraeger Berlin-Stuttgard, pp. 586.

Widiyanto, D. W., Djohor, D. S., Pramudito, H. and Untung (2014) "Studi penentuan fasies lingkungan pengendapan batubara dalam pemenfaatan potensi gas metana batubara di daerah Balikpapan, Kalimantan Timur berdasarkan analisis proximate dan petrografi," MINDAGI, 8(2), pp. 23-36. 